Blood Matters 
This page intentionally left blank 


\section{Blood Matters}

Studies in European Literature and Thought, I400-I700

Edited by

Bonnie Lander Johnson and Eleanor Decamp

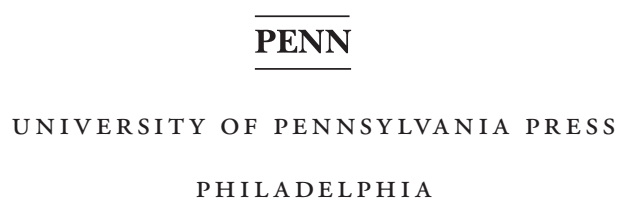


Copyright (C) 2018 University of Pennsylvania Press

All rights reserved. Except for brief quotations used for purposes of review or scholarly citation, none of this book may be reproduced in any form by any means without written permission from the publisher.

\author{
Published by \\ University of Pennsylvania Press \\ Philadelphia, Pennsylvania I9IO4-4II2 \\ www.upenn.edu/pennpress
}

Printed in the United States of America on acid-free paper

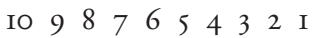

Library of Congress Cataloging-in-Publication Data

Names: Lander Johnson, Bonnie, editor. | Decamp, Eleanor, editor.

Title: Blood matters: studies in European literature and thought, I400-1700 / edited by Bonnie Lander Johnson and Eleanor Decamp.

Description: Ist edition. | Philadelphia: University of Pennsylvania Press, [2018] | Includes bibliographical references and index.

Identifiers: LCCN 20I7049245 | ISBN 97808I2250213 (hardcover: alk. paper)

Subjects: LCSH: Blood in literature. | Literature, Medieval-History and criticism. | European literature-Early modern, I500-1700-History and criticism. | Blood-Symbolic aspects—History. | Blood-Religious aspects-History. | Blood-Social aspects-History.

Classification: LCC PN682.B56 B58 2018 | DDC 809/.93356I-dc23

LC record available at https://lccn.loc.gov/2017049245 
Dedicated to Laurie Maguire 
This page intentionally left blank 